\title{
STANDARDIZATION OF GERMINATION TEST AND RESPONSE TO NACL SALT STRESS IN Toona cliliata SEEDS
}

\author{
Letícia Ramon de Medeiros ${ }^{1}$, Manoela Andrade Monteiro ${ }^{1}$, Patrícia Migliorini ${ }^{1}$, Marília Lazarotto ${ }^{2}$, \\ Lilian Madruga de Tunes ${ }^{3}$
${ }^{1}$ Universidade Federal de Pelotas, Programa de Pós Graduação em Ciência e Tecnologia de Sementes, Pelotas, Rio Grande do Sul, Brasil - leticiardemedeiros@gmail.com; manu_agro@hotmail.com; pati.migliorini@gmail.com
${ }^{2}$ Universidade Federal do Rio Grande do Sul, Departamento de Horticultura e Silvicultura, Porto Alegre, Rio Grande do Sul, Brasil - lilalazarotto@yahoo.com.br
${ }^{3}$ Universidade Federal de Pelotas, Departamento de Fitotecnia, Pelotas,Rio Grande do Sul, Brasil - lilianmtunes@ yahoo.com.br

Received for publication: 24/12/2014 - Accepted for publication: 03/08/2015

\begin{abstract}
The objective of this study was to evaluate the germination of Australian cedar seeds (Toona ciliata M. Roem) in three different substrates and two photoperiods and evaluate the effect of salt stress with sodium chloride $(\mathrm{NaCl})$ on the viability and vigor of seeds, conducting two experiments. The first experiment was conducted in a constant temperature room at $25 \mathrm{C}$ and two light regimes $12 \mathrm{~h} 24 \mathrm{~h}$ white light; and three substrates: sand, between paper and on paper. Evaluations were performed on the seventhand twenty-first day after sowing. Results were expressed as percentage of Normal Seedlings, Abnormal Seedlings and Dead Seeds, Number of True Leaves, Fresh, Dry Matter, Seedling Length and Root. The second experiment used constant $25 \mathrm{C}$ and photoperiod of 12 hours light. With treatments T1 (0mM: distilled water); $25 \mathrm{mMNaCl} \mathrm{T} 2 ; \mathrm{T} 350 \mathrm{mMNaCl}$; T4 and T5 $100 \mathrm{mMNaCl} 75 \mathrm{mMNaCl}$. We evaluated PCG, G, IVG, CP, CR. The photoperiod of $24 \mathrm{~h}$ light, does not influence the final seed germination and the use of paper on substrate provided the highest percentage of germinated seeds. As to the effect of salt stress, the concentration of $50 \mathrm{mMsalt}$, caused damage to the development of seedlings. Keywords: Forest seeds; analysis, vigor, salinity.
\end{abstract}

\section{Resumo}

Padronização do teste de germinação e resposta ao estresse salino por $\mathrm{NaCl}$ em sementes de Toona ciliata. O objetivo do trabalho foi avaliar a germinação de sementes de cedro australiano (Toona ciliata M. Roem) em três substratos com dois fotoperíodos e avaliar o efeito do estresse salino com cloreto de sódio $(\mathrm{NaCl})$ na viabilidade e vigor de sementes. O experimento I foi conduzido em ambiente com temperatura constante a $25^{\circ} \mathrm{C}$ e dois regimes de luminosidade, $12 \mathrm{~h}$ de $24 \mathrm{~h}$ de luz branca; três substratos: areia, entre papel e sobre papel. As avaliações foram realizadas no sétimo e vigésimo primeiro dia após a semeadura. Os resultados expressos em porcentagem de Plântulas Normais, Plântulas Anormais e Sementes Mortas, número de Folhas Verdadeiras, Massa Fresca, Massa Seca, Comprimento de Plântula e Raiz. O experimento II utilizou temperatura constante a $25^{\circ} \mathrm{C}$ e fotoperíodo de 12 horas luz. Com os tratamentos T1 (0 mM: água destilada); T2 $25 \mathrm{mMNaCl}$; T3 $50 \mathrm{mMNaCl}$; T4 $75 \mathrm{mMNaCl}$ e T5 $100 \mathrm{mMNaCl}$. Avaliando-se PCG, G, IVG, CP e CR. O fotoperíodo de $24 \mathrm{~h}$ de luz, não influencia na germinação e o uso do substrato sobre papel proporcionou a maior germinação. Quanto ao efeito do estresse salino, a concentração de $20 \mathrm{mM}$ de sal, prejudicou o desenvolvimento das plântulas.

Palavras-chave: Sementes florestais; análise de sementes, vigor, salinidade.

\section{INTRODUCTION}

Belonging to the botanic family of Meliaceae, the Australian Cedar (Toona ciliate M. Roem) is an exotic deciduous forest species that, in southwestern Brazil, blossoms between the months of September and November and bears fruits between January and March (KALIL FILHO;WENDLING, 2012). According to Queiroz et al. (2013), it is a species of rapid growth, very valorized in the furniture industry, because of its physical properties and its similarity with wood of Brazilian cedar (Cedrela odorata L.) and with other Cedrela species, has valuable woods for its technological properties, superior 
to the ones commercially used nowadays.

The species is studied due to the interest into diversification of species dedicated to forest production, because of rapid growth, reaching eight meters height and $15 \mathrm{~cm}$ diameter when three years old (PINHEIRO et al., 1994).

Germination is controlled by internal and external factors of the seed, like water content in soil, adequate temperature and oxygen availability, furthermore some seeds need to overcome the physiological status of dormancy (PESKE et al., 2006). Temperature is a determining factor for seeds germination, acting on water absorption capacity and on biochemical reactions behind the entire germination process (CARVALHO; NAKAGAWA, 2000). Light factor does not interfere with germination for the majority of seeds. However, it is important to avoid damages in seedlings development (PESKE et al., 2006). Another important factor to be considered is the substrate used for germination, which has the purpose to provide humidity and aeration to seeds, providing adequate conditions to germination and development of seedlings (PACHECO et al., 2006).

To proceed with evaluation of seeds quality of a given batch in laboratory, a germination standard is needed for each species, because every cultivation presents seeds with distinct characteristics in terms of physiological and germination behavior (WIELEWICK et al., 2006). T. ciliata has no germination standard recorded in the Seeds Analysis Rules (Regras para Análise de Sementes) (RAS), thus, seeds quality analysis is not possible.

After the analysis of germination and conditions for its achievement, other tests on reactions to adverse conditions for the species can be conducted. Percentage of germination is one of the most common methods to determine tolerance of plants to excess of salts (OLIVEIRA et al., 2007). Knowledge of tolerance to stress characteristics allows plantation in locations with significant incidence of salinity. Diminution of germination potential and reduction of seedlings strength when submitted to salts concentrations, compared to control, works as indicative of species tolerance to salinity (SILVA et al., 1992). The high concentration of salts is a stress factor for plants, because makes water less and less available (LARCHER, 2004). Researches demonstrated the negative effect of salinity on different species (CARMO et al., 2003; GURGEL et al., 2003; LIMA; TORRES, 2009).

Despite $T$. ciliate has been cultivated for some decades in the country and already exists cultivations that passed through cuttings and wood processing, researches related to production of seedlings and seeds are still at an early stage. Thus, there is need for more information on physiological quality of produced seeds, in order to look for more knowledge of the environmental conditions interfering with the germination process (GORDIN et al., 2012) and to provide efficient production of plantlets by seeds.

Due to the lack of information on germination standards of Australian cedar seeds and on its reaction to adverse environmental conditions, the present work had the objective to assess germination with different substrates and light regimes, and to assess the effect of salt stress with sodium chloride $(\mathrm{NaCl})$ on strength and viability of seeds for this species.

\section{MATERIAL AND METHODS}

The present work was conducted in two steps, being I) Evaluation of physiological quality of seeds under different photoperiods and substrates, II) Salt stress with $\mathrm{NaCl}$. Experiments were conducted in the Didactic Laboratory of Seeds Analysis of the Post-graduation program in Seeds Science and Technology of the Federal University of Pelotas, RS Brazil. Three batches of commercial seeds, collected in 2014 (from the states of Santa Catarina, São Paulo and Bahia) were used for the experiments. Seeds were homogenized, constituting a unique batch, and were stored in a cold and dry room, with a temperature of $15{ }^{\circ} \mathrm{C}$ and relative humidity of $35 \%$, until the beginning of the experiments.

\section{Evaluation of seeds physiological quality under different photoperiods and substrates}

The experiment was conducted in a controlled luminosity and temperature environment, in a Biochemical Oxigen Demand (B.O.D.) germination chamber, at constant temperature of $25^{\circ} \mathrm{C}$, two luminosity regimes, the first alternating $12 \mathrm{~h}$ of white light and $12 \mathrm{~h}$ dark, and the second with $24 \mathrm{~h}$ of white light. Three substrates were tested in two light conditions, sand, between paper towel and on paper towel, totalizing six treatments ( 2 photoperiods x 3 substrates). Seeds were disinfested with alcohol $70 \%$ (during 
30 seconds), sodium hypochlorite $1 \%$ (for two minutes) and consequently washed in distilled and sterilized water (for 30 seconds), before starting the germination tests.

Four replications of 50 seeds each were evaluated, giving 200 seeds per treatment. To assemble the tests, "germitest" paper roll was used for the between-paper germination test (EP), "gerbox" plastic boxes $(11.0 \times 11.0 \times 3.5 \mathrm{~cm})$ lined with two absorbent paper towel sheets for on-paper treatment (SP), and "gerbox" filled with $60 \mathrm{ml}$ of sand for the sand treatment. Paper towels in EP and SP tests were not sterilized, they were moistened with distilled water at a proportion of 2.5 times the dry-paper weight and, for the sand treatment and the quantity of water was $50 \%$ of the field capacity (MARTINS et al., 2008).

Physiological quality of seeds was evaluated by the following variables: a) the first counting of germination and total germination: (only normal seedlings), was made after seven days, and evaluation of the final germination after 21 days, considering normal seedlings, abnormal seedlings, hard and dead seeds. For all treatments, normal seedlings were considered the ones with developed roots and aerial part, according to Brasil (2009). After the 21 days, seedlings were assessed as following: b) length of the aerial part, measuring the aerial part of 10 seedlings of each replication. The average length of each seedling was obtained by the sum of measures of each replication, and dividing by the number of measured seedlings (KRZYZANOWSKI, 1991). c) length of roots: length of the primary root was obtained measuring the distance between the apical and basal part of the primary root, using a graduated ruler, according to (NAKAGAWA, 1999). d) fresh-mass of seedlings: measuring fresh-mass of 10 seedlings per replication; e) dry-mass of seedlings: 10 seedlings per replication were put into forced air oven at $70{ }^{\circ} \mathrm{C}$ for 24 hours, and then weighted on an analytic scale $(0.01 \mathrm{~g})$; $\mathrm{f}$ ) number of real seeds: obtained by counting all the leaves of seedlings (NAKAGAWA,1999).

\section{Salt stress with $\mathrm{NaCl}$}

This test was conducted into a B.O.D. type incubator chamber at constant $25^{\circ} \mathrm{C}$ temperature and photoperiod of 12 light hours. The used treatments were $0 \mathrm{mM}$ (distilled water), $25 \mathrm{mMNaCl}, 50$ $\mathrm{mMNaCl}, 75 \mathrm{mMNaCl}$ and $100 \mathrm{mMNaCl}$. The experimental design was in randomized blocks, with four replications of 50 seeds, totalizing 200 seeds per treatment of each batch used. Seeds were laid in a gerbox type case with absorbent paper towel moisturized at 2.5 times the mass of dry-paper with water solutions of sodium chloride $(\mathrm{NaCl})$, in different concentrations $(25,50,75$ and $100 \mathrm{mM})$, besides the control treated only with distilled water (control $-0 \mathrm{mM}$ ).

The analyzed variables were, a) first counting of germination: verified at seven days, as described in the previous test, b) normal plants: assessed at 21 days, also described in the previous item, c) germination velocity index: obtained from daily counting of germinated seeds, one day after plantation (minimum radicular protrusion from 3 to $4 \mathrm{~mm}$ ), d) length of the aerial part: measuring aerial part of 10 seedlings per replication, with a graduated ruler, e) rootlets length: primary root length was obtained measuring distance between the apical and basal part of the primary root, with a ruler, according to Nakagawa(1999).

Germination counting continued until the number of germinated seeds was constant, and germination velocity index was obtained according to recommendations of Nakagawa (1994). Average length of seedlings was obtained by the sum of measures of each replication, divided by the number of measured seedlings (KRZYZANOWSKI, 1991).

\section{Statistical analysis}

The completely randomized experimental design was applied to the germination test, with four replications in the factorial scheme (2x3), where photoperiod was the principal factor and substrate was the secondary factor. Data were submitted to analysis of variance and test $\mathrm{F}$ at $5 \%$ of probability. When $\mathrm{F}$ was significant, the test of Tukey at $5 \%$ was applied for comparison of means.

Data of the salt stress test on seeds were submitted to analysis of variance and regression, using the equation that better fitted to data. For each variable, a polynomial regression analysis was performed to verify behavior of variables in function of the different salt concentrations. All data were analyzed with the statistical software Sisvar 5.3 (FERREIRA, 2011).

\section{RESULTS AND DISCUSSION}

Interaction between photoperiods and substrates tested during germination of T. ciliata was not significant $(\mathrm{P}>0.05)$ for the following variables: First Counting of Germination (FCG), Standard 
Seedlings (SS), Abnormal Seedlings (A), Dead Seeds (DS), Root Length (RL) and Fresh Weight (FW). Therefore, the mean of treatments was calculated, and the analysis took place separately for each factor (Table 1). One can observe that only the variables FCG and FW showed differences between photoperiods, being the $24 \mathrm{~h}$ superior for both variables.

In the comparison of substrates, sand and on-paper substrate provided the higher percentage of SS. Furthermore, sand substrate provided increase of FCG and FW. However, the same substrate gave the higher number of dead seeds. Barbosa et al. (1988), aiming to determine adequate germination conditions of Tibouchina sellowiana Cogn seeds, tested different luminosity regimes, temperatures and substrates, observing that seeds showed higher strength under continuous light conditions and on-paper substrate, at a temperature of $30^{\circ} \mathrm{C}$.

Table 1. Mean (\%) of the first count of the germination (FCG) Standard seedlings (SS), Abnormal (A) and Dead Seeds (DS), root length (RL) and Fresh Weight of seedlings (FW) of Australian cedar, submitted to different photoperiod and substrates, Pelotas, Brazil.

Tabela1. Médias em percentagem da Primeira Contagem de Germinação (PCG), Plântulas Normais (PN), Anormais (PA) e Sementes Mortas (SM), Comprimento de Raiz (CR) e Massa Fresca de plântulas(MF) de cedro australiano, submetidas a diferentes fotoperíodos e substratos, Pelotas, RS.

\begin{tabular}{|c|c|c|c|c|c|c|}
\hline Photoperiod & $\begin{array}{c}\text { FGC } \\
(\%)\end{array}$ & $\begin{array}{l}\text { SS } \\
(\%)\end{array}$ & $\begin{array}{c}A \\
(\%)\end{array}$ & $\begin{array}{l}\text { DS } \\
(\%)\end{array}$ & $\begin{array}{c}\mathbf{R L} \\
\left(\mathbf{m m} \mathbf{p}^{-1}\right)\end{array}$ & $\begin{array}{c}\mathbf{F W} \\
\left(\mathrm{mg} \mathrm{p}^{-1}\right)\end{array}$ \\
\hline $12 \mathrm{~h}$ & $2.50 \mathrm{~b}$ & $50.88 \mathrm{a}$ & $11.33 \mathrm{a}$ & $38.05 \mathrm{a}$ & $29.39 \mathrm{a}$ & $30.68 \mathrm{~b}$ \\
\hline $24 \mathrm{~h}$ & $13.77 \mathrm{a}$ & $49.33 \mathrm{a}$ & $10.05 \mathrm{a}$ & $39.94 \mathrm{a}$ & $29.05 \mathrm{a}$ & $32.96 \mathrm{a}$ \\
\hline $\mathrm{CV}(\%)$ & 35.72 & 12.21 & 27.26 & 17.16 & 8.60 & 7.39 \\
\hline Susbtrate & $\begin{array}{c}\text { FGC } \\
(\%)\end{array}$ & $\begin{array}{l}\text { SS } \\
(\%)\end{array}$ & $\begin{array}{c} \\
(\%)\end{array}$ & $\begin{array}{l}\text { DS } \\
(\%)\end{array}$ & $\begin{array}{c}\mathrm{RL} \\
\left(\mathrm{mm} \mathrm{p}^{-1}\right)\end{array}$ & $\begin{array}{c}\text { FW } \\
\left(\mathrm{mg} \mathrm{p}^{-1}\right)\end{array}$ \\
\hline Sand & $12.16 \mathrm{a}$ & $48.25 \mathrm{ab}$ & $5.75 \mathrm{~b}$ & $44.50 \mathrm{a}$ & $13.40 \mathrm{c}$ & $38.45 \mathrm{a}$ \\
\hline Onpaper & $7.91 \mathrm{~b}$ & $55.16 \mathrm{a}$ & $12.25 \mathrm{a}$ & $32.66 \mathrm{~b}$ & $40.75 \mathrm{a}$ & $30.83 \mathrm{~b}$ \\
\hline BetweenPaper & $4.33 \mathrm{~b}$ & $46.91 \mathrm{~b}$ & $14.08 \mathrm{a}$ & $39.83 \mathrm{ab}$ & $33.52 \mathrm{~b}$ & $26.20 \mathrm{c}$ \\
\hline $\mathrm{CV}(\%)$ & 35.72 & 12.21 & 27.26 & 17.16 & 8.60 & 7.39 \\
\hline
\end{tabular}

This result demonstrates the in the $24 \mathrm{~h}$ photoperiod and in the sand and on-paper substrates, seeds showed higher strength, verified in FGC and RL. In the between-paper substrate (paper roll), there was higher percentage of abnormal seedlings and dead seeds, although there was no statistical difference comparing to the on-paper substrate.

Stockman et al. (2007), testing different temperatures and substrates, in germination tests of white-ipê seeds (Tabebuia roseo-alba (Ridl.) Sand.), verified that $30^{\circ} \mathrm{C}$ temperature and on-paper substrate was the most favorable condition for the germination test.

Analysis of variable Seedlings Length (SL), Number of True Leaves (NTL) and Dry Weight of seedlings (DW) resulted in significant interaction between photoperiod and substrate factors $(p<0.05)$. In the case of SL, between-paper substrate was superior in both light regimes tested (12 and 24h) and, comparing each photoperiod with the tested substrates, only in the on-paper substrate one could observe significant differences, and the $12 \mathrm{~h}$ photoperiod was superior (Table 2). In the case of NTL, for the $12 \mathrm{~h}$ photoperiod all substrates were equal, however, using $24 \mathrm{~h}$ light regime, sand substrate provided increase of this variable. In the case of DW, sand substrate was superior in both photoperiods. Fogaça et al. (2014), studying the substrate versus temperature interaction in pinhão-mansoseeds (Jatropha curcas L.), observed the best results in the sand substrate, maintained in germination chambers at $20-30^{\circ} \mathrm{C}$ and 8 hours photoperiod.

Lopes and Pereira (2005) reached similar results with cubiu seeds (Solanum sessiliflorum Dunal), at 25 and $30^{\circ} \mathrm{C}$ in between-sand and on-paper substrates. These authors also has the higher percentages and germination velocities compared to the other substrates, in the described conditions. Figliola (1984) reported significant interaction between substrate and temperature, and this is important, because water retention capacity of substrate and quantity of light beams allowed to reach seeds may be responsible for the different reactions obtained with the same temperature (AGUIAR et al., 1993).

Considering the salt stress, results obtained for the percentage of Germination (G) (Figure 1) show that $\mathrm{NaCl}$, in all concentrations tested, reduced the germination potential of Australian cedar seeds, and the most considerable reductions of the germination process was verified in concentrations starting from 50 $\mathrm{mM}$, with germination represented by a negative squared equation. 
Table 2. Means of photoperiod and substrates interaction for seedlings length (SL) Number of True leaves (NTL) and Dry weight (DW) of Australian cedar seedlings, Pelotas, Brazil

Tabela 2. Médias da interação fotoperíodo dos e substratos para Comprimento de Plântulas (CP),Número de Folhas Verdadeiras (NFV) e Massa Seca de plântulas (MS) de cedro australiano, Pelotas, RS.

\begin{tabular}{lcccccc}
\hline \multirow{2}{*}{ Substrates } & \multicolumn{2}{c}{ SL ( $\mathbf{m m} /$ seedling) } & \multicolumn{2}{c}{ NTL } & \multicolumn{2}{c}{ DW (g/seedling) } \\
\cline { 2 - 7 } & $\mathbf{1 2} \mathbf{~ h}$ & $\mathbf{2 4} \mathbf{~ h}$ & $\mathbf{1 2 ~ h}$ & $\mathbf{2 4} \mathbf{~ h}$ & $\mathbf{1 2 ~ h}$ & $\mathbf{2 4} \mathbf{~ h}$ \\
\hline Sand & $42.62 \mathrm{Ba}$ & $38.42 \mathrm{Ba}$ & $1.67 \mathrm{Aa}$ & $1.81 \mathrm{Aa}$ & $3.05 \mathrm{Aa}$ & $3.36 \mathrm{Aa}$ \\
Onpaper & $39.75 \mathrm{Ba}$ & $32.57 \mathrm{Cb}$ & $1.64 \mathrm{Aa}$ & $0.58 \mathrm{Bb}$ & $2.46 \mathrm{Ba}$ & $2.46 \mathrm{Ba}$ \\
Btw. paper & $54.99 \mathrm{Aa}$ & $59.23 \mathrm{Aa}$ & $1.50 \mathrm{Aa}$ & $0.04 \mathrm{Cb}$ & $2.15 \mathrm{Ba}$ & $1.88 \mathrm{Cb}$ \\
\hline CV $(\%)$ & \multicolumn{2}{c}{6,91} & \multicolumn{2}{c}{10,66} & & 7,15 \\
\hline
\end{tabular}

* Means followed by the same uppercase letter in the column and lowercase letter in the line are not significantly different by the test of Tukey at $5 \%$ of probability.

Similar results were observed in seeds of pau-de-jangada(Apeiba tibourbou Aubl.), where growing concentrations of $\mathrm{NaCl}$ resulted in decrease of germination performance (PACHECO et al., 2007). According to Lima and Torres (2009), salt stress provided reductions in germination and germination velocity in seeds of juazeiro(Zizyphus joazeiro Mart.).

Considering FCG (Figure 1), one could observe the behavior represented by a linear negative equation, with FCG linearly decreasing as $\mathrm{NaCl}$ concentrations increased.

Still in figure 1, the Germination Velocity Index (GVI) also was represented by a linear negative equation, because seeds started to germinate in a slower way starting from concentrations of $50 \mathrm{mM}$. Comparing percentage and velocity of germination, one could observe that curves have similar tendencies, allowing determination that faster germinating seeds were the ones presenting the higher percentage of germination, being this condition desirable in sowing activities, to have seeds germinating fast, uniformly and with greater percentage.

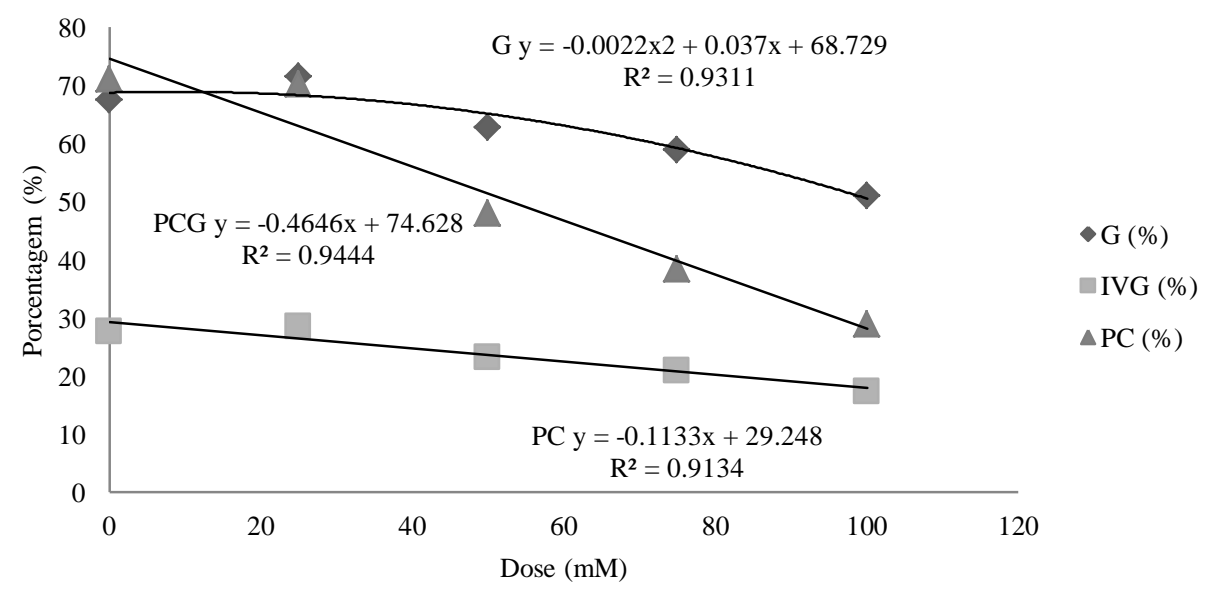

Figure 1. Representative Equations of Germination (G), First Count of germination (FCG) and Germination Velocity Index (GVI) of Toona ciliata seeds subjected to different concentrations of $\mathrm{NaCl}$.

Figura 1. Equações representativas da Germinação (G), Primeira Contagem de Germinação (PCG) e Índice de Velocidade de Germinação (IVG) de sementes de Toona ciliata submetidas a diferentes concentrações de $\mathrm{NaCl}$.

Values of primary root length of Australian cedar seedlings (Figure 2) showed progressive reduction, represented by a linear equation, when sodium chloride was added, suffering growth reduction starting from concentrations of $20 \mathrm{mM}$. Same as observed in the aerial part length of seedlings, which was stable in concentrations of $75 \mathrm{mM}$ and $100 \mathrm{mM}$, where the hypocotyl of seedlings measured 29.8 and $24.6 \mathrm{~mm}$ respectively. 
Similar findings were reported by Azevedo et al., (2003), with seeds of Sesamum indicum L., where length of the aerial part and the total length of seedlings were affected by increased salt concentrations. Oliveira et al. (2007) verified that increased salt concentrations caused height reduction in aroeira seedlings (Myracrodruon urundeuva FrAll) and Ribeiro et al. (2008), observed that height of sabiá seedlings (Mimosa caesalpiniaefolia Benth.) diminished, when submitted to salinity.

Soil generally contains important elements for plants growth, but high concentrations of the same elements might be toxic (FONSECA; PEREZ, 1999). Same as in the germination process and strength, salinity might somehow affect metabolism and chemical composition of seeds (BERTAGNOLLI et al., 2004).

When seeds are not adapted to suffer some kind of stress, like salinity, they become vulnerable to its effect, generating alterations in metabolism and even reduction of strength and germination potential (BERTAGNOLLI et al., 2004). It is known that seeds absorb less water when sowed in locations with excess of salt, because of the reduction in water potential(FERREIRA; REBOUÇAS, 1992).

Any increase in resistance to stresses of plants might avoid production losses in semi-arid locations, or give stability in regions where the adverse conditions are sporadic. Besides, it may support knowledge on behavior of species and on their management in field (MATOS et al., 2003). According to Bertagnolliet al. (2004), saline soils can be found in field, and seeds will have to be strong to resist to the adverse conditions of this environment.

Thus, one can deduce that Australian cedar has limitations in presence of salinity, because it presented reduction in germination and strength with all the assessed salt concentrations, being tolerant only up to about $25 \mathrm{mM}$. Because of that, a study on soil conditions is important in the location where the species will be planted, because otherwise there could be reduced growth or adaptation problems to environmental conditions, if the region happens to present high salinity.

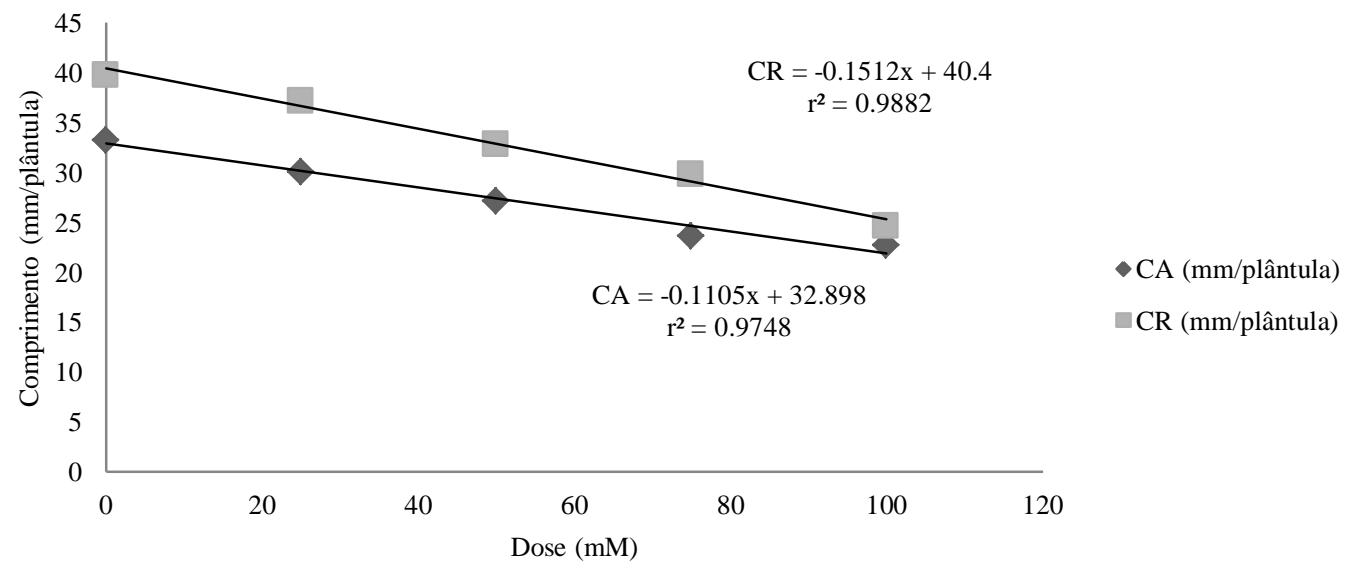

Figura 2. Equações representativas do comprimento da raiz primária (CR) e do comprimento da parte aérea (CA) das plântulas de Toona ciliata submetidas a diferentes concentrações de $\mathrm{NaCl}$.

Figure 2. Equations representing the length of the primary root (LPR) and shoot length (SL) of Toona ciliata seedlings subjected to different concentrations of $\mathrm{NaCl}$.

\section{CONCLUSION}

- The use of on-paper substrates, independently on photoperiod whether it was 12 or 24 hours of light, is suitable to conduct germination test of Toonaciliataseeds.

- Adverse effects of salt stress on germination and strength of seedlings of Toonaciliata are evident starting from concentrations of $20 \mathrm{mM}$ of $\mathrm{NaCl}$, which indicates that its use in reforestations of saline locations could be limited.

\section{REFERENCES}

AGUIAR, I.B.; PIÑA-RODRIGUES, F.C.M.; FIGLIOLIA, M.B. Sementes florestais tropicais. Brasília: ABRATES, 1993. 350p. 
AZEVEDO, M. R. Q. A.; ALMEIDA, F.A.C.; GOUVEIA, J.P.G.; AZEVEDO, C.A.V.; SILVA, M.M.; PORDEUS, R. V. Germinação e vigor no desenvolvimento inicial do gergelim: efeito da salinidade da água de irrigação. Revista Brasileira de Produtos Agroindustriais, Campina Grande, v.5, n. 2, p. 167$172,2003$.

BARBOSA, J.M.; BARBOSA, L. M.;PINTO, M.M.; AGUIAR, B. de. Efeito do substrato, temperatura e luminosidade na germinação de sementes de quaresmeira. Revista Brasileira de Sementes, v. 10, n. 3, p. 69-77, 1988.

BERTAGNOLLI, C.M.; CUNHA, C.; MENZES, S.; MORAES, D.; LOPES, N.; ABREU, C.Qualidade fisiológica e composição química de sementes de soja submetidas ao estresse salino. Revista Brasileira Agrociência, Pelotas, v. 10, n. 3, p. 287-291, 2004.

BRASIL. Ministério da Agricultura e Reforma Agrária. Regras para análise de sementes. Brasília: MAPA/ACS, 2009. 399 p.

CARMO, G.A.; MEDEIROS, J. F.; TAVARES, J. C. Crescimento de bananeiras sob diferentes níveis de salinidade da água de irrigação. Revista Brasileira de Fruticultura, Jaboticabal, v. 25, n.3, p. 513-518, 2003.

CARVALHO, N.M.; NAKAGAWA, J. Germinação de sementes. In: CARVALHO, N.M.; NAKAGAWA, J. (Ed.) Sementes: ciência, tecnologia e produção. Jaboticabal: FUNEP, 2000. p.128-166.

FERREIRA, D.F. Sisvar: a computerstatisticalanalysissystem. Ciência e Agrotecnologia, Lavras. v. 35, n.6, p. 1039-1042, 2011.

FERREIRA, L.G.R.; REBOUÇAS, M.A.A. Influência da hidratação/desidratação de sementes de algodão na superação de efeitos da salinidade na germinação. Pesquisa Agropecuária Brasileira, Brasília, v. 27, n. 4, p. 609-615, 1992.

FIGLIOLA, M.B. Influência da temperatura e substrato na germinação de sementes de algumas essências florestais nativas. In: SIMPÓSIO INTERNACIONAL: MÉTODOS DE PRODUÇÃO E CONTROLE DE QUALIDADE DE SEMENTES E MUDAS FLORESTAIS, 1984, Curitiba,Anais...Curitiba: UFPR, 1984. p.193-204.

FOGAÇA, C.A.; DA SILVA, L.L; POLIDORO, J.C.; BREIER, T.B.; LELES, P.S. dos S.; Metodologia para a condução do teste de germinação em sementes de (JatrophacurcasL.). In: <http://oleo.ufla.br/anais_04/artigos/pdfs/a4206.pdf>; Acesso em: 15/12/2014.

FONSECA, S.C.L.; PEREZ, S.C.J.G. A. Efeito de sais e da temperatura na germinação de sementes de olho-de-dragão (Anadenanthera pavonina L.-FABACEAE). Revista Brasileira de Sementes, Pelotas, v. 21, n. 2, p. 70-77, 1999.

GORDIN, C.R.B.; MARQUES, R.F.; MASETTO, T.E.; SCALCON, S. de P.Q. Germinação, biometria de sementes e morfologia de plântulas de Guizotia abyssinica Cass. Revista Brasileira de Sementes, Dourados. v. 34, n. 4, p. 619-627, 2012.

GURGEL, M.T.; FERNANDES, P.D.; GHEYI,H.R.; SANTOS,F.J.S.; BEZERRA, I.L.; NOBRE, R.G. Estresse salino na germinação e formação porta-enxerto de aceroleira. Revista Brasileira de Engenharia Agrícola e Ambiental, Campina Grande, v. 7, n. 1, p. 31-36,2003.

LOPES, J.C.; PEREIRA, M.D. Germinação de sementes de cubiu em diferentes substratos e temperaturas. Revista Brasileira de Sementes, Pelotas. v.27, n.2, p.146-150, 2005.

KALIL FILHO,A.N.; WENDLING, I. Produção de mudas de CedroAustraliano. Comunicado Técnico 309, Embrapa.Colombo,5p., 2012.

KRZYZANOWSKI, F.C. Teste de comprimento de raiz de plântula de soja. Informativo ABRATES, Brasília, v.2, n.1, p.11-14, 1991.

LARCHER, W. Ecofisiologia Vegetal. São Carlos: Rima, 2004, 531 p.

LIMA, B.G.; TORRES, S.B. Estresses hídrico e salino na germinação de sementes de ZizyphusjoazeiroMart. (Rhamnaceae). Revista Caatinga, Mossoró, v. 22, n. 4, p. 93-99,2009. 
MARTINS,C.C.; MACHADO, C.G.; NAKAGAWA, J.Temperatura e substrato para o teste de germinação de sementes de barbatimão (Stryphnodendron adstringens (Mart.) Coville (Leguminosae). Revista Árvore, Viçosa.v.32,n.4, p. 633-639, 2008.

MATOS, N.N.; TEXEIRA JUNIOR, A.C.; SILVEIRA, J.A.G. Influência do porta-enxerto no comportamento fisiológico de mudas de cajueiro (Anacardium occidentale L.) submetidas a estresses. Revista Brasileira de Fruticultura, Jaboticabal, v. 25, n. 1, p. 27-31, 2003.

NAKAGAWA, J. Testes de vigor baseados no desempenho das plântulas. In: KRZYZANOSKI, F.C.; VIEIRA, R.D.; FRANÇA NETO, J.B. (Ed.).Vigor de sementes: conceitos e testes.Londrina:ABRATES, 1999. p.2.1-2.24.

NAKAGAWA, J. Testes e vigor baseados na avaliação de plântulas. In: VIEIRA, R.D.; CARVALHO, N.M. (Ed.). Testes de vigor em sementes. Jaboticabal: FUNEP, 1994, p. 49-85.

OLIVEIRA, A. M.; LINHARES, P.C.F.; MARACAJA, P.R.B.; RIBEIRO, M.C.; BENEDITO, C.P. Salinidade na germinação e desenvolvimento de plântulas de aroeira (Myracrodruon urundeuva Fr. All). Caatinga, Mossoró, v. 20, n. 2, p. 39 - 42, 2007.

PACHECO, M.V.;MATOS, V.P.; FERREIRA, R.L.C.; FELICIANO, A.L.P. Germinação de sementes de ApeibatibourbouAubl. submetidas ao estresse salino. Cerne, Lavras, v.13, p. 41-46, 2007.

PACHECO, M.V.; MATOS, V.P.; FERREIRA, R.L.C.; FELICIANO, A.L.P.; PINTO, K.M.S. Efeito de temperaturas e substratos na germinação de sementes de Myracrodruon urundeuva Fr. All. (Anacardiaceae). Revista Árvore, Viçosa, v.30, n.3, p.359-367, 2006.

PESKE, S.T.; LUCCA FILHO, O.A.; BARROS, A.C.S.A. Sementes: fundamentos científicos e

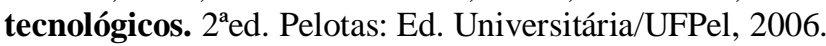

PINHEIRO, A.L.; RAMALHO, R.S.; BARREIROS, H.S. Árvores exóticas em Viçosa: II.,Toona ciliata M. Roem. var.australis (F. V. M.) C. DC. (MELIACEAE). Revista Ceres, Viçosa, v. 41, n. 234, p. 103112, 1994.

QUEIROZ, D.L.; BURCKHARDT, D.; ANJOS, D. Psilídeos no Brasil: 8 - Mastigimasanjosi (Hemiptera, Psylloidea), nova praga da Toona ciliata no Brasil. Colombo: Embrapa Florestas. (Comunicado técnico, 313), 7 p., 2013.

RIBEIRO, M.C.C.; BARROS, N.M.S.; BARROS JR., A.P.; SILVEIRA, L.M. Tolerância do sabiá (Mimosa caesalpiniifolia Benth.) à salinidade durante a germinação e o desenvolvimento de plântulas. Caatinga, Mossoró, v. 21, n. 5, p. 123-126, 2008.

SILVA, M.J.; SOUZA, J.G.; NETO, M.B.; SILVA, J.V. Seleção de três cultivares de algodoeiro para tolerância à germinação em condições salinas. Pesquisa Agropecuária Brasileira, Brasília, v. 27, n. 4, p. 655-659, 1992.

STOCKMAN, A.L.; BRANCALIONP, H.S.; NOVEMBREA, D.daL. C.; CHAMMA,H.M.C.P. Sementes de ipê-branco (Tabebuia roseo-alba(Ridl.) Sand. - Bignoniaceae): temperatura e substrato para o teste de germinação. Revista Brasileira de Sementes,Londrina, v.29,p.130-143, n.3,2007.

WIELEVICKI, A.P.; LEONHARDT, C.; SCHLINDWEIN, G.; MEDEIROS, A.C.S. Proposta de padrões de germinação e teor de água para sementes de algumas espécies florestais presentes na região sul do Brasil. Revista Brasileira de Sementes, Brasília, v. 28, n. 3, p.191-197, 2006. 